\title{
DNA Analysis Detects Different Mislabeling Trend by Country in European Cod Fillets
}

\author{
Frederik Feldmann, Alba Ardura *, Carmen Blanco-Fernandez and Eva Garcia-Vazquez
}

Citation: Feldmann, F.; Ardura, A. Blanco-Fernandez, C.;

Garcia-Vazquez, E. DNA Analysis Detects Different Mislabeling Trend by Country in European Cod Fillets. Foods 2021, 10, 1515. https:// doi.org/10.3390/foods10071515

Academic Editors: Rosalee S. Hellberg and Robert Hanner

Received: 9 June 2021

Accepted: 27 June 2021

Published: 30 June 2021

Publisher's Note: MDPI stays neutral with regard to jurisdictional claims in published maps and institutional affiliations.

Copyright: (c) 2021 by the authors. Licensee MDPI, Basel, Switzerland. This article is an open access article distributed under the terms and conditions of the Creative Commons Attribution (CC BY) license (https:// creativecommons.org/licenses/by/ $4.0 /)$.
Department of Functional Biology, University of Oviedo, C/Julian Claveria s/n, 33006 Oviedo, Spain; frederik.feldmann@imbrsea.eu (F.F.); blancofmaria@uniovi.es (C.B.-F.); egv@uniovi.es (E.G.-V.)

* Correspondence: arduraalba@uniovi.es; Tel.: +34-985-10-30-76

\begin{abstract}
Atlantic cod, Gadus morhua, is a highly appreciated fish in European seafood markets and is one of the most substituted fish species in the world. Fraud have been detected in European markets in the last decade, finding different substitute species sold as G. morhua or Atlantic cod on the label. In this study, we analyzed 252 samples of fresh and frozen cod fillets sold in Germany, the Netherlands, and France using DNA barcoding. Different trends were found in different countries: while the level of mislabeling found in Germany and the Netherlands remained at zero in the last years, a significant increase was found in the French markets comparing the current results with previous studies on fillets in France. On the one hand, this mislabeling proves the need to encourage European efforts to control seafood authenticity; on the other, zero mislabeling in two countries shows the success of current European regulations.
\end{abstract}

Keywords: Atlantic cod; barcoding; mislabeling; European markets

\section{Introduction}

Mislabeling of fishery products has been and still is common practice worldwide, as has been described in different studies conducted around the world in Africa [1], North America [2], South America [3], Asia [4], or Europe [5], for example. One of the reasons behind this practice is the increase of the global seafood consumption, which has doubled within the last 50 years [6]. A total of $76 \%$ per capita seafood consumption in the EU consists of wild catch products as opposed to aquaculture ones, with a subsequent price inflation for fishery products [7]. Although this trend has been drastically reversed with the COVID-19 pandemic due to the decrease of the demand for exported fishery products [8], Germany and Italy show an increase in household consumption of fresh seafood, whereas in other EU member states, the overall consumption is decreasing [9].

To allow traceability and guarantee strict product labelling for consumers within the EU, European Regulation EU 1379/2013, Art. 35, established on 11 December 2013, dictates that EU member states must publish a list of commercially traded seafood species, including scientific names. This also includes the area where the product was caught and the fishing methods used, as some methods, such as bottom trawling, can be very disruptive to the ecosystem [10]. Despite those implementations, mislabeling in the EU is still commonly reported [11]. Differences in mislabeling have been observed between different selling points, such as restaurants or catering services and retailers and supermarkets, with recent high rates of mislabeling in German mass catering [11,12]. Beyond the environmental and conservation implications, due to over- or under-representation on the catching statistics [13], mislabeling can also influence public health, as surrogate species can induce allergic outbreaks in sensitive consumers [14]. Therefore, appropriate labelling is very important from any point of view.

Identifying the species based on morphological features is often difficult for the consumer because processed fish usually lack the parts that enable their better identification, 
such as heads, tails, or fins, and the appearance and taste of different species might be similar. This is the reason why molecular methods, such as barcoding, are used for identification purposes. Barcoding has been proven to be effective and has also become cheaper over the last decade [15]. This process usually involves the extraction, amplification, and sequencing of different fragments, such as the mitochondrial cytochrome c oxidase I subunit gene (COI), since $\mathrm{COI}$ is suitable for unambiguous identification of many vertebrates, including fish at species level $[16,17]$; for these reasons, it is the barcode of choice employed in the first marine barcoding projects $[18,19]$. The DNA sequences are then edited and compared with the sequences found in data bases, such as the National Center for Biotechnology Information (NCBI) or Barcode of Life Data System (BOLD) [20].

Cod, Gadus morhua, is one of the most substituted species in the world [21]. Especially in the EU, the consumption of cod shows an increasing trend over the last decade, while the consumption of other species of groundfish remains generally low. It is only in the last two years that cod consumption has been declining, driven by a decline in imports and catches [8]. One factor for the decrease in catches could be the emerging cod farming industry, which, in the case of Norway, competes strongly with the fishing industry, especially since the diet of the cod is not entirely based on fish and may include soybeans [22]. Cod aquaculture has also shown to be more profitable compared to fishing, contributing to curb the dependence on the fishing industry [23]. In addition, the growing awareness of the environmental effects of large-scale fishing could contribute to cut down the consumption of fishing products. In any case, the price of Atlantic cod increased significantly in early 2020 due to Commission Regulation (EU) 2020/183, Art. 1-3, establishing a fishery closure for cod in areas 1 and $2 \mathrm{~b}$. This regulation might encourage incorrect labelling by introducing cheaper species to substitute the more expensive cod. Therefore, this study focuses on G. morhua as a target species. Nonetheless, in some countries like Belgium, recent mislabeling seems to be very low [24]. In other places like the Netherlands, no mislabeling of G. morhua/Gadus macrocephalus has been detected so far although this country has only been assessed once, showing the gaps of sampling efforts throughout Europe [25]. To this irregular sampling is added the fact that publications on seafood mislabeling featuring cod are scarce and inconsistent through the years. Germany, for example, has recently shown high mislabeling rates within common sole samples [26] and general mislabeling in other fish species [11,27], but not many studies have been conducted on mislabeling of G. morhua. Previous studies showed high percentages of mislabeling in fresh and frozen fillets/products [28,29]. In France, in 2015, the first study was developed to evaluate the extent of the mismatch between the market names and the actual species for some of the most common commercial marine fish species, including cod as one of the most often-substituted species. [30].

It is relevant to highlight the importance of knowing the mislabeling rates and the most frequent substitute species because seafood fraud not only affects the ability of consumers to make informed and sustainable seafood purchases, but it also harms fisheries and fishermen, allowing the introduction of illegal catches, or not declared ones, into the food markets [25]. There are several strategies to improve food quality control and traceability at all stages in the chain production of different product types (e.g., fresh and frozen products or recognizable or processed products) sold in different retail outlet types (e.g., supermarkets, restaurants, or fish markets). Among them, the genetic techniques used for species identification, such as the DNA barcoding, could improve the monitoring activities if used as a routine monitoring tool. However, despite its importance, there is a considerable lack of knowledge about mislabeling in different types of cod products. While recent studies reported higher occurrences of mislabeling in salted products [31], other ones do not mention the product types in detail [25]. Many studies do not specify the rate of mislabeling between the different locations when sampled in different retail outlets $[5,32]$. Other studies showed opposite trends: more mislabeling in supermarkets [28] or more mislabeling in fish markets [30]. 
Therefore, since fresh and frozen products have been found to contain mislabeled cod, the principal aims of this study are: (i) to analyze a large sample of cod products in fish markets and supermarkets of three European countries: Germany, the Netherlands and France; (ii) to compare the obtained results between countries; (iii) to compare these results with the mislabeling levels found in Europe in the last decade; and (iv) to highlight the species most commonly used as a substitute for cod.

\section{Materials and Methods}

\subsection{Sampling and Labelling}

A total of 252 fresh or frozen fillets labelled as G. morhua were sampled randomly from supermarkets or fish markets in Fulda, Hamburg, and Bremerhaven in Germany; Rotterdam in the Netherlands; and Sète and Montpellier in France. A total of 101 samples were taken from Germany, of which 28 were from fish markets and 73 from supermarkets. In all, 71 samples were obtained from the Netherlands, of which 30 samples were from fish markets and 41 from supermarkets. Then, 80 samples were taken from France, with 57 samples from supermarkets and 23 from fish markets. The names of the stores of purchase and the information displayed on the label, such as distributors and the catching methods, were noted (Table 1). For all samples, the scientific name was displayed on the label. Since some samples were sold as G. morhua and G. macrocephalus as one product, it was decided to include G. macrocephalus in the study as well. Tissue samples were cut from the fillets and stored in $5 \mathrm{~mL}$ Eppendorf tubes with twist-off caps filled with $98 \%$ ethanol to avoid spoilage during the travel.

Table 1. Samples analyzed in this study and the information provided in the labels. Each sample was coded with the information of the fish, its condition (fresh/frozen), the country, city, and store of purchase. Fre, fresh; Fro, frozen; Ger, Germany; Net, the Netherlands; Fra, France; N/A, not available data. Supermarket/fish market names are not provided to keep confidentiality. (e.g., CodFroNetRA1 = Cod, Frozen, Netherlands, Rotterdam, store A).

\begin{tabular}{|c|c|c|c|c|c|c|c|}
\hline $\begin{array}{l}\text { Sample } \\
\text { Number }\end{array}$ & $\begin{array}{c}\text { Species in } \\
\text { Label }\end{array}$ & Country & $\begin{array}{l}\text { Number of } \\
\text { Samples }\end{array}$ & City & $\begin{array}{c}\text { Selling } \\
\text { Point }\end{array}$ & $\begin{array}{c}\text { Catch } \\
\text { Method }\end{array}$ & $\begin{array}{c}\text { Catch } \\
\text { Location }\end{array}$ \\
\hline CodFreGerHW & G. morhua & Germany & 4 & Hamburg & Fish market & trawl nets & $\begin{array}{l}\text { Barents Sea } \\
\text { (FAO 27) }\end{array}$ \\
\hline CodFreGerHF & G. morhua & Germany & 10 & Hamburg & Fish market & trawl nets & $\begin{array}{c}\text { Norwegian } \\
\text { Sea (FAO 27) }\end{array}$ \\
\hline CodFreGerBS & G. morhua & Germany & 10 & Bremerhaven & Fish market & trawl nets & $\begin{array}{l}\text { Great Belt } \\
\text { (FAO 27) }\end{array}$ \\
\hline CodFreGerHAF & G. morhua & Germany & 2 & Hamburg & Fish market & $\mathrm{N} / \mathrm{A}$ & $\mathrm{N} / \mathrm{A}$ \\
\hline CodFreGerFN & G. morhua & Germany & 2 & Fulda & $\begin{array}{l}\text { Fish market } \\
\text { chain }\end{array}$ & seine fishing & $\begin{array}{c}\text { North } \\
\text { Atlantic } \\
\text { Ocean } \\
\text { (FAO 27) }\end{array}$ \\
\hline CodFreGerFE & G. morhua & Germany & 3 & Fulda & Supermarket & $\mathrm{N} / \mathrm{A}$ & $\begin{array}{c}\text { Norwegian } \\
\text { Sea (FAO 27) }\end{array}$ \\
\hline CodFreGerFT & G. morhua & Germany & 4 & Fulda & Supermarket & $\mathrm{N} / \mathrm{A}$ & $\begin{array}{l}\text { Iceland } \\
\text { (FAO 27) }\end{array}$ \\
\hline CodFroGerHL & G. morhua & Germany & 6 & Hamburg & Supermarket & various & FAO 27 \\
\hline CodFroGerHA & G. morhua & Germany & 6 & Hamburg & Supermarket & $\begin{array}{l}\text { bottom otter } \\
\text { trawl }\end{array}$ & $\begin{array}{c}\text { Spitzbergen, } \\
\text { Barents Sea } \\
\text { (FAO 27) }\end{array}$ \\
\hline CodFroGerFT & G. morhua & Germany & 10 & Fulda & Supermarket & various & $\begin{array}{l}\text { Barents Sea/ } \\
\text { Norwegian } \\
\text { Sea/North } \\
\text { East Atlantic } \\
\text { (FAO 27) }\end{array}$ \\
\hline
\end{tabular}


Table 1. Cont

\begin{tabular}{|c|c|c|c|c|c|c|c|}
\hline $\begin{array}{l}\text { Sample } \\
\text { Number }\end{array}$ & $\begin{array}{c}\text { Species in } \\
\text { Label }\end{array}$ & Country & $\begin{array}{l}\text { Number of } \\
\text { Samples }\end{array}$ & City & $\begin{array}{c}\text { Selling } \\
\text { Point }\end{array}$ & $\begin{array}{l}\text { Catch } \\
\text { Method }\end{array}$ & $\begin{array}{c}\text { Catch } \\
\text { Location }\end{array}$ \\
\hline CodFroGerFR & G. morhua & Germany & 8 & Fulda & Supermarket & $\begin{array}{c}\text { seine } \\
\text { fishing/long } \\
\text { lines }\end{array}$ & $\begin{array}{c}\text { Barents Sea/ } \\
\text { Norwegian } \\
\text { Sea (FAO 27) }\end{array}$ \\
\hline CodFroGerFK & G. morhua & Germany & 10 & Fulda & Supermarket & $\begin{array}{c}\text { trawl } \\
\text { nets/NA }\end{array}$ & $\begin{array}{l}\text { North East } \\
\text { Atlantic/ } \\
\text { (FAO 27) }\end{array}$ \\
\hline CodFroGerFL & $\begin{array}{c}\text { G. } \\
\text { morhua/G. } \\
\text { macro- } \\
\text { cephalus }\end{array}$ & Germany & 16 & Fulda & Supermarket & various & $\begin{array}{c}\text { North East } \\
\text { Atlantic } \\
\text { (FAO 27)/ } \\
\text { North East } \\
\text { Pacific } \\
\text { (FAO 67) }\end{array}$ \\
\hline CodFroGerBA & G. morhua & Germany & 2 & Bremerhaven & Supermarket & $\begin{array}{l}\text { bottom otter } \\
\text { trawl }\end{array}$ & $\begin{array}{c}\text { Barents Sea } \\
\text { (FAO 27) } \\
\text { Norwegian } \\
\text { Sea }\end{array}$ \\
\hline CodFroGerFA & G. morhua & Germany & 8 & Fulda & Supermarket & trawl nets & FAO 27 \\
\hline CodFreNetRVg & G. morhua & $\begin{array}{l}\text { The Nether- } \\
\text { lands }\end{array}$ & 10 & Rotterdam & Fish market & $\mathrm{N} / \mathrm{A}$ & $\begin{array}{l}\text { North Sea } \\
\text { (FAO 27) }\end{array}$ \\
\hline CodFreNetBd & G. morhua & $\begin{array}{l}\text { The Nether- } \\
\text { lands }\end{array}$ & 14 & Rotterdam & Fish market & $\mathrm{N} / \mathrm{A}$ & $\begin{array}{l}\text { Norway } \\
\text { (FAO 27) }\end{array}$ \\
\hline CodFreNetRN & G. morhua & $\begin{array}{l}\text { The Nether- } \\
\text { lands }\end{array}$ & 1 & Rotterdam & Fish market & $\mathrm{N} / \mathrm{A}$ & $\mathrm{N} / \mathrm{A}$ \\
\hline CodFreNetRVb & G. morhua & $\begin{array}{l}\text { The Nether- } \\
\text { lands }\end{array}$ & 5 & Rotterdam & Fish market & $\mathrm{N} / \mathrm{A}$ & $\begin{array}{l}\text { North Sea } \\
\text { (FAO 27) }\end{array}$ \\
\hline CodFroNetRA & G. morhua & $\begin{array}{l}\text { The Nether- } \\
\text { lands }\end{array}$ & 21 & Rotterdam & Supermarket & $\begin{array}{c}\text { seine } \\
\text { fishing/long } \\
\text { lines }\end{array}$ & $\begin{array}{l}\text { North East } \\
\text { Atlantic, } \\
\text { Barents Sea, } \\
\text { North Sea } \\
\text { (FAO 27) }\end{array}$ \\
\hline CodFroNetRH & G. morhua & $\begin{array}{c}\text { The Nether- } \\
\text { lands }\end{array}$ & 20 & Rotterdam & Supermarket & $\begin{array}{l}\text { trawl nets, } \\
\text { seine } \\
\text { fishing/long } \\
\text { lines }\end{array}$ & $\begin{array}{l}\text { North East } \\
\text { Atlantic, } \\
\text { Barents Sea, } \\
\text { North Sea } \\
\text { (FAO 27) }\end{array}$ \\
\hline CodFreFraMCf & G. morhua & France & 3 & Montpellier & Supermarket & $\begin{array}{l}\text { hooks, long } \\
\text { lines }\end{array}$ & $\begin{array}{l}\text { Iceland, Faroe } \\
\text { Islands } \\
\text { (FAO 27) }\end{array}$ \\
\hline CodFreFraMAu & G. morhua & France & 5 & Montpellier & Supermarket & $\begin{array}{l}\text { trawls, } \\
\text { hooks long } \\
\text { lines }\end{array}$ & $\begin{array}{c}\text { Faroe Islands, } \\
\text { Barents Sea } \\
\text { (FAO 27) }\end{array}$ \\
\hline CodFreFraSCc & G. morhua & France & 7 & Sète & Fish market & trawls & FAO 27 \\
\hline CodFreFraSCl & G. morhua & France & 8 & Sète & Fish market & trawls & FAO 27 \\
\hline CodFreFraSPr & G. morhua & France & 5 & Sète & Fish market & trawls & FAO 27 \\
\hline CodFreFraSCk & G. morhua & France & 3 & Sète & Fish market & trawls & FAO 27 \\
\hline CodFroFraMCar & G. morhua & France & 23 & Montpellier & Supermarket & $\begin{array}{l}\text { hooks, long } \\
\text { lines, trawls }\end{array}$ & $\begin{array}{c}\text { Barents Sea } \\
\text { Faroe Islands } \\
\text { FAO 27Ice- } \\
\text { land } \\
\text { (FAO 27) }\end{array}$ \\
\hline CodFroFraMSu & G. morhua & France & 12 & Montpellier & Supermarket & $\begin{array}{l}\text { hooks, long } \\
\text { lines, trawls }\end{array}$ & $\begin{array}{c}\text { Barents Sea, } \\
\text { Norwegian } \\
\text { Sea, } \\
\text { (FAO 27) }\end{array}$ \\
\hline CodFroFraMAu & G. morhua & France & 14 & Montpellier & Supermarket & $\begin{array}{l}\text { hooks, long } \\
\text { lines, trawls }\end{array}$ & $\begin{array}{l}\text { Barents Sea, } \\
\text { Norwegian } \\
\text { Sea, North Sea } \\
\text { (FAO 27) }\end{array}$ \\
\hline
\end{tabular}




\subsection{DNA Extraction}

DNA extraction was done following the chelex protocol described by Estoup et al. [33]. Briefly, a small sample of the tissue was cut and placed in a $1.5 \mathrm{~mL}$ tube; then, $500 \mu \mathrm{L}$ of chelex and $7.5 \mu \mathrm{L}$ of proteinase $\mathrm{k}$ were added. The samples were then placed in an oven at $55^{\circ} \mathrm{C}$ for $1 \mathrm{~h} 1 / 2$ and shaken every $15 \mathrm{~min}$. To inactivate the proteinase $\mathrm{k}$, the samples were heated at $100{ }^{\circ} \mathrm{C}$ for $20 \mathrm{~min}$. The samples that did not give a successful DNA yield were re-extracted using the DNAeasy tissue kit (Qiagen, Hileden Germany) following the manufacturers' protocol.

\subsection{PCR and DNA Sequencing}

A DNA region within the Cytochrome Oxidase subunit I gene (COI thereafter) was amplified using the primers FISHCO1 described by Handy et al. [34] and successfully applied in cod [29]:

FISHCO1LBC: $5^{\prime}$-TCAACYAAT CAYAAAGATATYGGCAC- $3^{\prime}$

FISHCO1HBC: $5^{\prime}$-ACTTCYGGGTGRCCR AARAATCA-3'

This primer set was used to streamline the sequencing but also to allow for a longer read in the COI gene [34]. The PCR was performed following the protocol described by Pinto et al. [29].

In order to confirm the genetic identification, a second marker, the universal primers described by Ward et al. [35], were used to amplify a region within the gene coding for the COI. The PCR was adjusted and performed in a final mixture of $20 \mu \mathrm{L}$ and included $1 \mu \mathrm{L}$ of each primer $(10 \mu \mathrm{M}), 4 \mu \mathrm{L}$ of Taq buffer, $2 \mu \mathrm{L}$ dNTP $(2.5 \mathrm{mM}), 2 \mu \mathrm{L} \mathrm{MgCl}_{2}(25 \mathrm{mM})$, $0.15 \mu \mathrm{L}$ Taq polymerase $(5 \mathrm{U} / \mathrm{mL})$, and $7.85 \mu \mathrm{L}$ water. The thermal profile for all primers was as follows: the first step at denaturing $94^{\circ} \mathrm{C}$ for $5 \mathrm{~min}, 35$ cycles of $45 \mathrm{~s}$ at $94{ }^{\circ} \mathrm{C}, 45 \mathrm{~s}$ at $50{ }^{\circ} \mathrm{C}$, and $72{ }^{\circ} \mathrm{C}$ at $1 \mathrm{~min}$. The final elongation step was set at $72{ }^{\circ} \mathrm{C}$ for $4 \mathrm{~min}$.

For visualization of the amplified PCR products, an electrophoresis ( $2 \%$ agarose and $2.5 \mu \mathrm{L}$ SimplySafe, EURx, Poland) was performed using $4 \mu \mathrm{L}$ of ladder and $4 \mu \mathrm{L}$ of DNA.

The samples were sent to Macrogen Inc. (Madrid, Spain) to sequence the amplified PCR products using the Sanger sequencing method procedure.

\subsection{Data Analysis}

In order to generate consensus sequences for each specimen, the obtained chromatograms from the sequencing were edited using BioEdit v7.2.6.1. [36], and the quality of the peaks was visually checked. The presence of NUMTs was checked with MEGA-X software and GenBank database, checking the coding frame before to make the accession numbers available for the scientific community. The edited sequences were uploaded to the BLASTn search tool in GenBank (www.ncbi.nlm.nih.gov, National Institutes of Health de Estados Unidos, 15 January 2021) to identify the species of the sequence obtained. The species of the best-match hit was chosen as putative species, using an identity threshold $>97 \%$ for COI barcode, as indicated in Ward et al. [35]. Sequences labelled as voucher specimen were used since this ensures a physical copy of the specimen. In the case that no voucher specimen was found in the NCBI database, sequences with reference title of a published article were used.

The information declared on the label and/or by the sellers, such as the common and scientific name of the species of the fish product sold on the markets (Table 1), was compared to the results derived from the molecular identification analysis. A few samples with best-match bacteria sequences were labelled as degraded, meaning that the DNA of the fish sample was too disintegrated by the bacteria, and discarded.

Haplotype analysis was conducted using DNAsp in order to upload one sequence per haplotype obtained in this study of G. morhua or G. macrocephalus in NCBI.

The conservation status and annual fishery quotes of the substitute species found in literature were derived from the IUCN red list and the FAO annual catching report. 


\subsection{Statistical Analysis}

A linear regression analysis of the variable "\% of mislabeled samples" over time since the first mislabeling report in 2008 was conducted to assess spatial trends. A chi-square analysis was performed to check changes of mislabeling in cod fillets between current (our study) and past samples in the countries considered. For both statistical tests, the statistical significance was set to 0.05 . We included data from literature and the data derived from our samples.

Statistical analysis was conducted in Microsoft EXCEL. To visualize the data the statistical R (version 3.6.1) software, QGIS and Microsoft EXCEL were used.

\section{Results}

\subsection{DNA Analysis}

Of the 252 samples collected for this study (Table 1), 203 samples were successfully extracted and amplified, and negative controls were performed. From the successfully extracted samples, $171(84.2 \%)$ of the obtained sequences from this analysis compared to NCBI gave successful matches ranging between $97-100 \%$ of pairwise sequences identity with reference sequences present in the database. Five samples showed best hits with $G$. morhua sequences but with identity below $97 \%$, and 18 samples were below the $90 \%$ pairwise sequence identity. Since they did not display unambiguous chromatograms (some nucleotide peaks were not clear), they were labelled as degraded. The negative controls run along the PCRs were all negative, demonstrating lack of contamination during the laboratory process.

All the samples from Germany and the Netherlands analysed in this study, for which barcodes were obtained, were correctly labelled regarding the species declared on the label. Nine of 26 samples (25\%) from France were mislabeled, displaying haplotypes from Melanogrammus aeglefinus. Haplotypes obtained for G. morhua matching 100\% to previous uploaded haplotypes are available on the GenBank database (www.ncbi.nlm.nih.gov, 15 January 2021): G. morhua GB-AN (MW020365-MW020375).

\subsection{Catch Location and Catch Method}

All samples that displayed catch areas on the labels had them within FAO 27 as catch location for G. morhua and FAO 67 for the catch location of G. macrocephalus (Table 1). The most common catch method reported was trawl nets. None of the fish obtained in Germany was caught from the North Sea, whereas the fish purchased in the Netherlands had North Sea as the catch location labelled on the product. All the samples from France were labelled as G. morhua, contained information about the catch method, and the capture area was stated as FAO 27 in some samples and North, Barents, and Norwegian seas in others (Table 1).

\subsubsection{Proportion of Mislabeling over Time}

Observing the evolution of cod mislabeling (G. morhua/G. macrocephalus) within the EU over the last decade, including our samples in 2020 (Table 2), the linear regression was negative and statistically significant $\left(\mathrm{y}=-0.021 \mathrm{x}+41.543, \mathrm{r}^{2}=0.44 ; 9\right.$ d.f.; $\left.p=0.04\right)$.

On the other hand, while the mislabeling in cod fillets was 0 in Germany and the Netherlands in the last decade, and it was still 0 in 2020, the changes in French markets was statically significant $\left(\chi^{2}=17.79 ; \mathrm{df}=1 ; p<0.001\right)$, with 2 cases of mislabeling found over 95 samples analysed taken from the bibliography (Table 2) and 9 cases of mislabeling found over 36 samples barcoded in this study. 
Table 2. Number of mislabeled cod within the EU from literature. Year of sampling, number of correctly and incorrectly labelled samples, country, species reported on the label, and the published reference are given.

\begin{tabular}{|c|c|c|c|c|c|}
\hline $\begin{array}{l}\text { Year of } \\
\text { Sampling }\end{array}$ & $\begin{array}{l}\text { Correctly } \\
\text { Labelled }\end{array}$ & $\begin{array}{l}\text { Incorrectly } \\
\text { Labelled }\end{array}$ & $\begin{array}{l}\text { Sampling } \\
\text { Country }\end{array}$ & Species on Label & Reference \\
\hline 2008 & 4 & 2 & Italy & G. morhua & $\begin{array}{l}\text { Filonzi et al. } 2010 \\
\text { (Appendix A) [37] }\end{array}$ \\
\hline 2010 & 94 & 37 & Ireland & Cod & $\begin{array}{l}\text { Miller and Mariani 2010 } \\
\text { (Appendix A) [32] }\end{array}$ \\
\hline 2012 & 88 & 7 & UK & Cod & $\begin{array}{l}\text { Miller, Jessel, and Mariani } 2012 \\
\text { (Appendix A) [28] }\end{array}$ \\
\hline 2013 & 43 & 62 & Italy & Cod & $\begin{array}{l}\text { Pinto et al. 2013 } \\
\text { (Appendix A) [29] }\end{array}$ \\
\hline 2013 & 512 & 34 & Spain & G. morhua & $\begin{array}{l}\text { Helgoe et al. 2020 } \\
\text { (Appendix A) [31] }\end{array}$ \\
\hline 2013 & 2 & 2 & Italy & Cod & $\begin{array}{l}\text { Cutarelli et al. } 2013 \\
\text { (Appendix A) [38] }\end{array}$ \\
\hline 2013 & 136 & 6 & France & Cod & $\begin{array}{l}\text { Benard-Capelle et al. } 2015 \\
\text { (Appendix A) [30] }\end{array}$ \\
\hline 2014 & 5 & 0 & Portugal & $\begin{array}{l}\text { G. morhua/G. } \\
\text { macrocephalus }\end{array}$ & $\begin{array}{l}\text { Harris et al. 2016 } \\
\text { (Appendix A) [39] }\end{array}$ \\
\hline 2014 & 48 & 0 & France & Cod & $\begin{array}{l}\text { Mariani et al. } 2015 \\
\text { (Appendix A) [5] }\end{array}$ \\
\hline 2014 & 42 & 0 & Germany & Cod & $\begin{array}{l}\text { Mariani et al. } 2015 \\
\text { (Appendix A) [5] }\end{array}$ \\
\hline 2014 & 55 & 1 & Ireland & Cod & $\begin{array}{l}\text { Mariani et al. } 2015 \\
\text { (Appendix A) [5] }\end{array}$ \\
\hline 2014 & 67 & 4 & Portugal & $\begin{array}{l}\text { Cod, G. morhua/G. } \\
\text { macrocephalus }\end{array}$ & $\begin{array}{l}\text { Mariani et al. } 2015 \\
\text { (Appendix A) [5] }\end{array}$ \\
\hline 2014 & 118 & 4 & Spain & Cod & $\begin{array}{l}\text { Mariani et al. } 2015 \\
\text { (Appendix A) [5] }\end{array}$ \\
\hline 2014 & 138 & 8 & UK & Cod & $\begin{array}{l}\text { Mariani et al. } 2015 \\
\text { (Appendix A) [5] }\end{array}$ \\
\hline 2014 & 170 & 9 & UK & Cod & $\begin{array}{l}\text { Helyar et al. } 2014 \\
\text { (Appendix A) [40] }\end{array}$ \\
\hline 2015 & 43 & 0 & Norway & Cod & $\begin{array}{l}\text { Brechon et al. } 2016 \\
\text { (Appendix A) [25] }\end{array}$ \\
\hline 2015 & 44 & 0 & Netherlands & Cod & $\begin{array}{l}\text { Brechon et al. } 2016 \\
\text { (Appendix A) [25] }\end{array}$ \\
\hline 2015 & 13 & 19 & Estonia & Cod & $\begin{array}{l}\text { Brechon et al. } 2016 \\
\text { (Appendix A) [25] }\end{array}$ \\
\hline 2015 & 43 & 0 & Belgium & Cod & $\begin{array}{l}\text { Brechon et al. } 2016 \\
\text { (Appendix A) [25] }\end{array}$ \\
\hline 2015 & 41 & 1 & UK & Cod & $\begin{array}{l}\text { Brechon et al. 2016 } \\
\text { (Appendix A) [25] }\end{array}$ \\
\hline 2015 & 35 & 8 & Denmark & Cod & $\begin{array}{l}\text { Brechon et al. } 2016 \\
\text { (Appendix A) [25] }\end{array}$ \\
\hline 2015 & 43 & 2 & Sweden & Cod & $\begin{array}{l}\text { Brechon et al. } 2016 \\
\text { (Appendix A) [25] }\end{array}$ \\
\hline 2016 & 49 & 5 & Spain & Cod & $\begin{array}{c}\text { Muñoz-Colmenero et al. } 2016 \\
\text { (Appendix A) [41] }\end{array}$ \\
\hline 2016 & 62 & 11 & Belgium & Cod & $\begin{array}{l}\text { Christiansen et al. } 2018 \\
\text { (Appendix A) [42] }\end{array}$ \\
\hline 2016 & 41 & 6 & Spain & G. morhua & $\begin{array}{l}\text { Pardo and Jimenez } 2020 \\
\text { (Appendix A) [43] }\end{array}$ \\
\hline 2017 & 7 & 3 & Portugal & G. Morhua/Cod & $\begin{array}{l}\text { Pardo et al. } 2018 \\
\text { (Appendix A) [11] }\end{array}$ \\
\hline 2017 & 2 & 1 & France & Cod & $\begin{array}{l}\text { Pardo et al. } 2018 \\
\text { (Appendix A) [11] }\end{array}$ \\
\hline 2017 & 1 & 1 & Czech Republic & Cod & $\begin{array}{l}\text { Pardo et al. } 2018 \\
\text { (Appendix A) [11] }\end{array}$ \\
\hline
\end{tabular}


Table 2. Cont.

\begin{tabular}{|c|c|c|c|c|c|}
\hline $\begin{array}{l}\text { Year of } \\
\text { Sampling }\end{array}$ & $\begin{array}{l}\text { Correctly } \\
\text { Labelled }\end{array}$ & $\begin{array}{l}\text { Incorrectly } \\
\text { Labelled }\end{array}$ & $\begin{array}{l}\text { Sampling } \\
\text { Country }\end{array}$ & Species on Label & Reference \\
\hline 2017 & 1 & 1 & Greece & Cod & $\begin{array}{l}\text { Pardo et al. } 2018 \\
\text { (Appendix A) [11] }\end{array}$ \\
\hline 2017 & 4 & 1 & UK & $\begin{array}{l}\text { G. morhua/G. } \\
\text { macrocephalus }\end{array}$ & $\begin{array}{l}\text { Pardo et al. } 2018 \\
\text { (Appendix A) [11] }\end{array}$ \\
\hline 2017 & 0 & 1 & Finland & $\begin{array}{l}\text { G. morhua/G. } \\
\text { macrocephalus }\end{array}$ & $\begin{array}{l}\text { Pardo et al. 2018 } \\
\text { (Appendix A) [11] }\end{array}$ \\
\hline 2017 & 1 & 1 & Latvia & $\begin{array}{l}\text { G. morhua/G. } \\
\text { macrocephalus }\end{array}$ & $\begin{array}{l}\text { Pardo et al. } 2018 \\
\text { (Appendix A) [11] }\end{array}$ \\
\hline 2017 & 1 & 1 & Switzerland & $\begin{array}{l}\text { G. morhua/G. } \\
\text { macrocephalus }\end{array}$ & $\begin{array}{l}\text { Pardo et al. } 2018 \\
\text { (Appendix A) [11] }\end{array}$ \\
\hline 2017 & 1 & 0 & Germany & Cod & $\begin{array}{l}\text { Pardo et al. } 2018 \\
\text { (Appendix A) [11] }\end{array}$ \\
\hline 2017 & 2 & 0 & Belgium & Cod & $\begin{array}{l}\text { Pardo et al. } 2018 \\
\text { (Appendix A) [11] }\end{array}$ \\
\hline 2017 & 3 & 0 & Norway & Cod & $\begin{array}{l}\text { Pardo et al. } 2018 \\
\text { (Appendix A) [11] }\end{array}$ \\
\hline 2017 & 2 & 0 & Italy & Cod & $\begin{array}{l}\text { Pardo et al. } 2018 \\
\text { (Appendix A) [11] }\end{array}$ \\
\hline 2017 & 1 & 0 & Netherlands & Cod & $\begin{array}{l}\text { Pardo et al. } 2018 \\
\text { (Appendix A) [11] }\end{array}$ \\
\hline 2017 & 3 & 0 & Ireland & G. morhua & $\begin{array}{l}\text { Pardo et al. } 2018 \\
\text { (Appendix A) [11] }\end{array}$ \\
\hline 2018 & 10 & 0 & Greece & Cod & $\begin{array}{l}\text { Minoudi et al. } 2020 \\
\text { (Appendix A) [44] }\end{array}$ \\
\hline 2019 & 70 & 4 & UK, Belgium & $\begin{array}{c}\text { G. macro- } \\
\text { cephalus/G.morhua }\end{array}$ & $\begin{array}{l}\text { Barendse et al. } 2019 \\
\text { (Appendix A) [45] }\end{array}$ \\
\hline 2019 & 42 & 1 & UK & Cod & $\begin{array}{c}\text { Barendse et al. } 2019 \\
\text { (Appendix A) [45] }\end{array}$ \\
\hline 2019 & 111 & 3 & Belgium & G. morhua & $\begin{array}{l}\text { Deconinck et al. 2020 } \\
\text { (Appendix A) [24] }\end{array}$ \\
\hline 2020 & 71 & 0 & Netherlands & G. morhua & This study \\
\hline 2020 & 101 & 0 & Germany & $\begin{array}{l}\text { G. morhua/G. } \\
\text { macrocephalus }\end{array}$ & This study \\
\hline 2020 & 27 & 9 & France & G. morhua & This study \\
\hline
\end{tabular}

\subsubsection{Substitute Species}

The analysis including previous and current results showed differences in the substitute species among countries, considering only recurrent substitutions (substitute species appearing only once, in one study, were not taken into account in this analysis for simplicity). Especially, saithe (Pollachius virens) has been often found as a substitution species, making up the majority of substitute species in Italy, Ireland, Belgium, and Estonia. Haddock (M. aeglefinus) has been determined to be the dominant substitute species in France, Sweden, and Denmark, being the only substitute species in Sweden and Denmark and $84.6 \%$ of the substitute species found in France. The United Kingdom has high proportions of G. morhua, G. macrocephalus, and M. aeglefinus as substitute species. Both ways, G. morhua and G. macrocephalus were substituted for each other. Relatively high percentages of ling (Molva molva) were found in Spain, whereas Pollachius pollachius was found to be used more frequently in Ireland. The number and variety of substitute species was not the same in all countries, the highest diversity occurring in Spain, followed by Belgium and the United Kingdom (Figure 1). The different substitute species found on different years are summarized on the Table 3. P. virens and M. aeglefinus were found in nearly all papers through the years, including this current study, followed by Gadus chalcogrammus. 


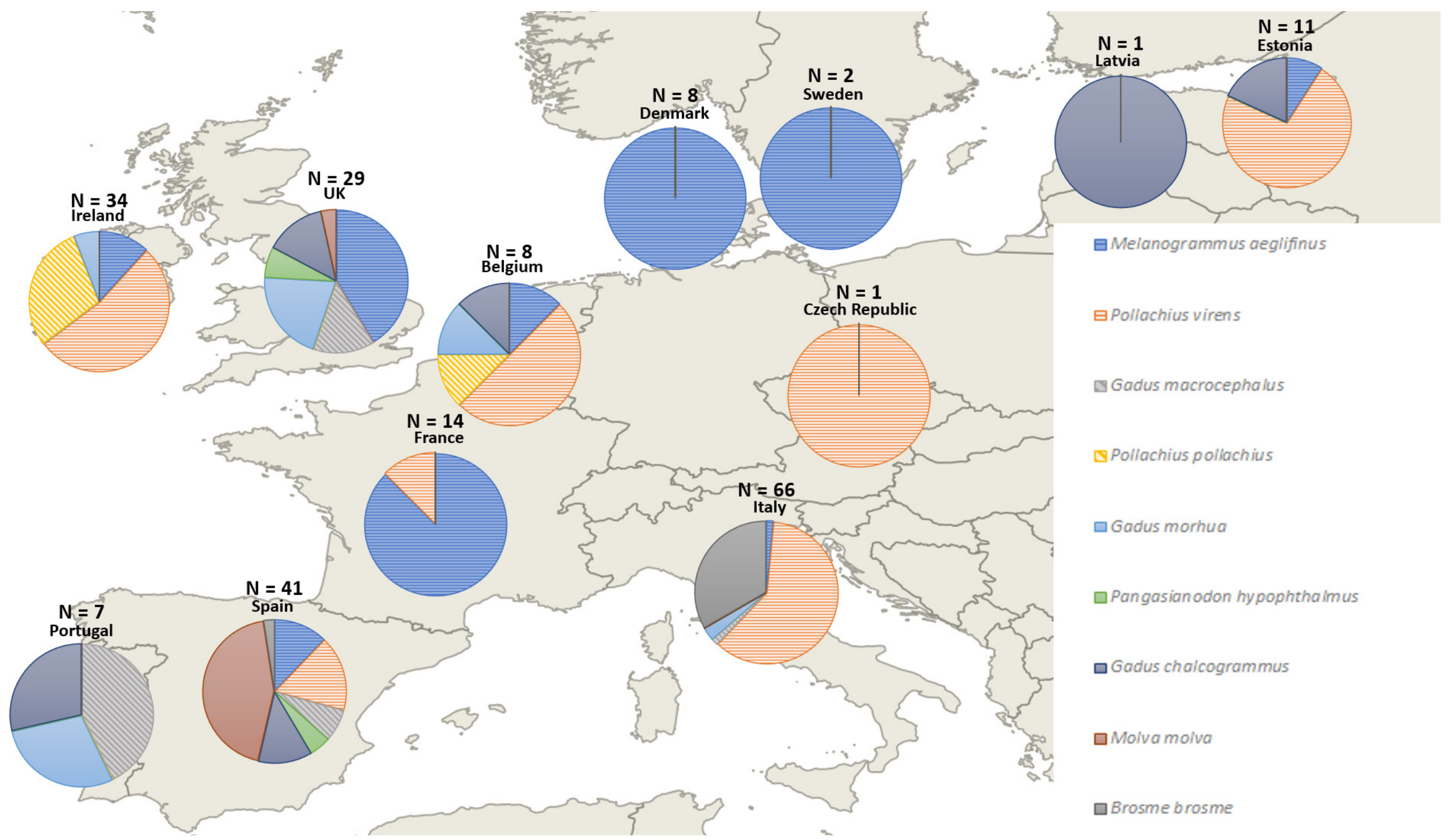

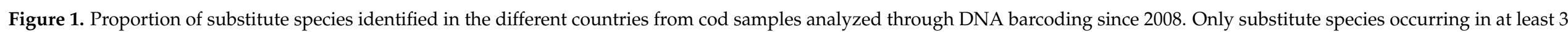
different publications or having at least $\mathrm{N}=10$ were used in this figure. 
Table 3. The years each substitute species was found (G. morhua was substitute species of G. macrocephalus). IUCN, International Union for Conservation of Nature.

\begin{tabular}{ccc}
\hline Substitute Species & IUCN Status & Years of Occurrence \\
\hline Gadus morhua & Vulnerable & $2010,2012,2014,2019$ \\
G. macrocephalus & Not evaluated & $2013,2014,2019$ \\
Lates niloticus & Least concern & 2013,2016 \\
G. chalcogrammus & Near threatened & $2013,2015,2016,2017,2019$ \\
Molva molva & Data deficient & $2013,2014,2016,2017$ \\
Pangasianodon hypophtalmus & Endangered & $2012,2013,2017$ \\
Pollachius pollachius & Least concern & 2010,2016 \\
P. virens & Least concern & $2010,2013,2015,2016,2017,2019$ \\
Melanogrammus aeglefinus & Vulnerable & $2010,2012,2013,2014,2015,2019,2020$ \\
\hline
\end{tabular}

\section{Discussion}

Mislabeling is a challenge to biological diversity. Since seafood products are becoming increasingly diverse in a globalized world, it is harder for the consumer to accurately identify the products, which makes it more crucial to correctly label them [21]. This also applies to processed seafood or even fillets, as sampled for this study. Zero mislabeling in unrecognizable cod products (fresh and frozen) was found in samples from 15 selling points in different German cities and 7 in Rotterdam. However, nine (25\%) of our samples collected from eight different selling points in two cities in France were mislabeled. Although a higher mislabeling in Germany due to recent peaks of species substitution in seafood [11,26,27], most of them in restaurants, could be expected, it was not found in our study for fillets. In the same way, the expectation on finding mislabeled Atlantic cod in the Netherlands due to the reduced fishing quotas as stated in Commission Regulation (EU) 2020/123, Art. 1-3 and increased value of the fish also was not confirmed. Only in France was mislabeling found. It had been reported in fillets in this country with a modest $2 \%$ of mislabeling [5,25], but it increased significantly, up to $25 \%$, in the current study.

On the other hand, the outcome of this study would partially confirm previous studies, such as that of Mariani et al. [5], who, based on the rather low rate of mislabeling around 2014, suggested that seafood mislabeling within the EU was generally decreasing, as our Figure 2 shows for cod. Our results suggest that this would not be entirely true for all the countries in 2020. This was also proposed by Brechon et al. [25], who found low levels of mislabeling in cod products but also found a high variation between sampled countries, with Denmark and Estonia displaying higher mislabeling rates than the other EU countries. However, no previous studies on cod mislabeling have been conducted in both countries; thus, the country trend could not be known. This can be explained in country-specific dynamics on a governmental level [25] but also from the different levels in the awareness of substitution fraud in different countries driven by media exposure [46]. Countries such as Ireland, in which high mislabeling rates have been exposed [31] in the first wave of mislabel reports between 2008 and 2010 (there are no references for years prior to 2008), displayed lower mislabeling levels in supermarkets and fish markets later [5]. However, this is not necessarily the case for restaurants and mass catering, as Pardo and Jimenez [43] found in Spain and Christiansen et al. [42] in Brussels, with mislabeling rates up to 13\% in restaurants and $25 \%$ of cod mislabeling in the mass catering sector in the whole of Europe [11].

A higher number of different substitute species can be detected when it comes to the inclusion of restaurants or takeaway shops in the studies $[11,42,43,47]$. Countries which have been sampled predominantly in supermarkets or fish markets do not show this trend [5]. In combination with the higher mislabeling rates in these selling points, it could imply active mislabeling, since EU labelling and traceability regulation are less strict for restaurants [26]. However, more studies should be conducted for confirmation. 


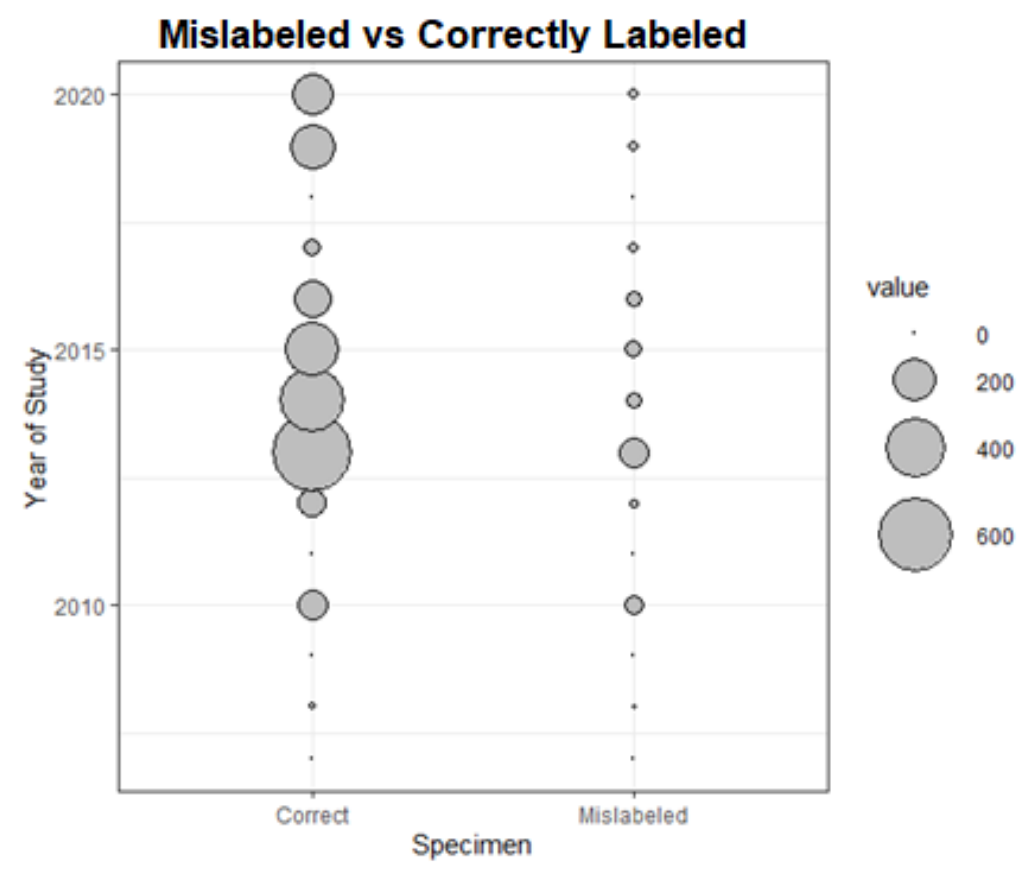

Figure 2. Mislabeled cod products in comparison to correctly labelled products over time within EU countries; value $=$ sample size.

Although there is an apparent reduction of mislabeling for the EU [5,30], certain substitute species remain frequently used through the years (Table 3). Pollachius virens and M. aeglefinus, as such, appears in seven years of a total of nine years analysed, including the current study. As one of the species with the highest substitution proportions re-occurring through the studies, $P$. virens is still listed as a species of least concern in the IUCN data base and with relatively low catching rates, with mean annual number of 349,026 tons in comparison to G. morhua, with mean annual catching number of 1,124,884 tons in the last decade. Therefore, the population of $P$. virens does not seem to be affected too much, but the available catch data is not accurate. Haddock (M. aeglefinus), on the other hand, also a frequently used substitute species in Denmark, Sweden, or France, as the only species found as substituted for cod, is listed as vulnerable in the IUCN database. Although its annual catch rate is similar to that of $P$. virens, this demonstrates how dangerous mislabeling can be for a specific population, since the catch is not reported and the stocks are already under pressure. The price of $2.79 € /$ kilogram is also below the value of cod, which ranges between $4 €$ and $10.90 €$ (FAO February 2020). This could be a driving factor behind the mislabeling since less valuable fish can potentially be sold for a higher value. G. chalcogrammus also appears frequently as substitute species but proportionately less than $P$. virens and $M$. aeglefinus. This is despite the fact that the species was listed as near threatened in the IUCN database in 2013. However, its status changed in 2019 to not evaluated since it is often used as an ingredient in processed food, and its value has been reported as $1.51 €(\mathrm{FAO}$, February 2020); a current stock assessment is necessary. G. macrocephalus and G. morhua have also occurred as substitution species most frequently of each other. Some stores (Table 1), however, sell them together labelled as cod and stating both scientific names. These practices should be further regulated under the EU law since G. macrocephalus is not evaluated in the IUCN list, but G. morhua is listed as vulnerable. The official annual number of total catches for $G$. macrocephalus (391,292 tons) are also lower than for G. morhua $(1,124,884$ tons).

The cod market, as one of the most studied seafood species/products [21], shows positive signals towards successful increased control since the proportion of mislabeled cod is decreasing over the last decade despite the increase of studies. But not only should the detection of mislabeling be a responsibility of science, it should be implemented in the EU 
law to take routine controls in all levels; EU-wide normatives should be implemented to standardize those controls. Furthermore, new technologies like fisheries electronic monitor systems could be applied to help programmes based on inspectors and observers. Tools like facial recognition software could be adapted to recognize the fish species caught [48]. In addition, samples should be collected at every selling point regularly as standard control under EU regulation.

On the other hand, it is important to highlight the lack of information about the fishing methods used in samples obtained from fish markets for fresh cod products in Germany and the Netherlands since tags with more detailed information were missing and the fishmongers were often not informed either. This contests the standards of the Regulation (EU) No 1379/2013 by the CMO of the European Parliament and Council stating that processed or unprocessed food from fishery or aquaculture products need to be labelled or marked with the information on the exact species, how the species was produced, and its origin. Moreover, we found the use of fishery techniques declared as destructive by the European Union through the (CFP) Common Fisheries Policy [49], such as bottom otter trawling. Some products sampled for this study have their catch region labelled as FAO 27 or FAO 27 and FAO 67 when the product was labelled to consist either of G. morhua or G. macrocephalus. The area FAO 27 includes all the regions within the Northeast Atlantic, including catching areas of all European coastal countries from Portugal to Norway but also Iceland and Greenland [50]. The area FAO 67 consists of all marine waters bounded by a line commencing from a point at mainland Russia in the Eastern Bering Sea, crossing through Alaska and Canada and departing within USA territory [51]. However, not every country shares the same catch quotes [52]. Norway, Iceland, or Great Britain, for example, are not bound to EU regulation and thus have different fishing quotas. Cod stocks in the North Sea are still overexploited and therefore unsustainable [52], but this is not the case for the cod stocks of the Barents Sea [53]. Since both areas are covered by the FAO 27 area, it is not clear if the product comes from a sustainably managed stock or not. Sadly, the European Regulation EU 1379/2013, Art. 35 only specifies the area of fishing to be labelled and not the subarea. EU fishing vessels seeking to fish outside European waters must comply with the sustainable management of external fishing fleets regulation (SMEFF). However, the SMEFF stays silent when it comes to cooperation in the management of unregulated high sea stocks, includes poor monitoring practices (e.g., reflagging and chartering), lacks coherence regarding sustainability criteria, and does not provide public access to data on beneficial ownership [54]. This undermines the effort on traceability provided by the Regulation (EU) No 1379/2013 since any catch locations outside the EU (FAO 67 and certain areas within FAO 27 (e.g., Barents Sea)), falls under the SMEFF regulation.

Finally, only fifteen scientific investigations with complete, comparable information were found from 2008 to 2020 that checked labelling correctness of cod in the EU (Table 2). This, together with inconsistent sample sizes ranging from 6 to 546 samples and lack of data in $2009,2011,2018$, and prior years, makes it difficult to determine a defined trend.

\section{Conclusions}

Over the last decade, the general trend of mislabeled cod within the EU is significantly negative, which is very positive for the conservation of G. morhua and G. macrocephalus and testifies of increased awareness, probably thanks to more publications and media coverage. This trend is positive, too, for their substitute species, especially for those listed as vulnerable, endangered, and critically endangered fish species. However, there are different trends in cod fillets in the three markets analysed, with a significant increment in French markets.

Therefore, although the general trend is decreasing, the differences found in different markets highlight the need of implementation of standard controls on different selling points and fish products.

Author Contributions: Conceptualization, E.G.-V.; methodology, C.B.-F.; formal analysis, F.F.; investigation, F.F.; resources, E.G.-V.; writing—original draft preparation, F.F.; writing—review and 
editing, A.A. and E.G.-V.; supervision, E.G.-V. and A.A.; funding acquisition, E.G.-V. All authors have read and agreed to the published version of the manuscript.

Funding: This research was funded by Spanish Ministry of Science and Innovation, grant number GLOBALHAKE PID2019-108347RB-I00.

Institutional Review Board Statement: Not applicable.

Informed Consent Statement: Not applicable.

Data Availability Statement: Accession numbers of all analyzed sequences are present into the text.

Acknowledgments: We acknowledge the support given by Laura Voces with laboratory tasks and the support given by Jané Salazar Mcloughlin when encountering issues with R. Thanks to Luis Sánchez Aznar, Alberto Cabal Álvarez, and Juan López Llames for their help in lab tasks. Thanks to Aida Dopico for proofreading the manuscript.

Conflicts of Interest: The authors declare no conflict of interest.

\section{Appendix A}

Table A1. Accession Numbers from the Publications Used in the Study, If Provided.

\begin{tabular}{ll}
\hline Publication & Sequence Accession Number \\
\hline Filonzi et al., 2010 [38] & GenBank: EU7521, DQ173995, EU752090, \\
Miller and Mariani, 2010 [32] & EF211102 \\
Miller, Jessel, and Mariani, 2012 [28] & not provided \\
Pinto et al., 2013 [29] & not provided \\
Helgoe et al., 2020 [30] & not provided \\
Cutarelli et al., 2013 [39] & not provided \\
Benard-Capelle et al. 2015 [33] & Barcode of Life: FCSF001-14 to FCSF291-14; \\
Harris et al. 2016 [40] & FCSF292-14 to FCSF404-14 \\
Mariani et al., 2015 [32] & not provided \\
Helyar et al., 2014 [41] & GenBank: KJ510424-KJ531384; \\
Brechon et al., 2016 [25] & KJ563141-KJ645864 \\
& GenBank: KJ614671-KJ615069 \\
Muñoz-Colmenero et al., 2016 [42] & not provided \\
& GenBank: KF597025-KF597028; KF597030; \\
Christiansen et al., 2018 [43] & KF597040-KF597046; KF597048; \\
Pardo and Jimenez, 2020 [44] & KP330299-KP330373; KP330374-KP330387 \\
Pardo et al., 2018 [11] & not provided \\
Minoudi et al., 2020 [45] & GenBank: MT266987-MT267272 \\
Barendse et al., 2019 [46] & not provided \\
Deconinck et al., 2020 [24] & not provided \\
\hline
\end{tabular}

\section{References}

1. Galal-Khallaf, A.; Ardura, A.; Mohammed-Geba, K.; Borrell, Y.J.; Garcia-Vazquez, E. DNA Barcoding Reveals a High Level of Mislabelling in Egyptian Fish Fillets. Food Control 2014, 46, 441-445. [CrossRef]

2. Khaksar, R.; Carlson, T.; Schaffner, D.W.; Ghorashi, M.; Best, D.; Jandhyala, S.; Traverso, J.; Amini, S. Unmasking Seafood Mislabelling in U.S. Markets: DNA Barcoding as a Unique Technology for Food Authentication and Quality Control. Food Control 2015, 56, 71-76. [CrossRef]

3. Carvalho, D.C.; Guedes, D.; da Gloria Trindade, M.; Coelho, R.M.S.; de Lima Araujo, P.H. Nationwide Brazilian Governmental Forensic Programme Reveals Seafood Mislabelling Trends and Rates Using DNA Barcoding. Fish. Res. 2017, 191, 30-35. [CrossRef]

4. Xiong, X.; Guardone, L.; Cornax, M.J.; Tinacci, L.; Guidi, A.; Gianfaldoni, D.; Armani, A. DNA barcoding reveals substitution of sablefish (Anoplopoma fimbria) with Patagonian and Antarctic toothfish (Dissostichus eleginoides and Dissostichus mawsoni) in online market in China: How mislabeling opens door to IUU fishing. Food Control 2016, 70, 380-391. [CrossRef] 
5. Mariani, S.; Griffiths, A.M.; Velasco, A.; Kappel, K.; Jerome, M.; Perez-Martin, R.I.; Schroder, U.; Verrez-Bagnis, V.; Silva, H.; Vandamme, S.G.; et al. Low Mislabelling Rates Indicate Marked Improvements in European Seafood Market Operations. Front. Ecol. Environ. 2015, 13, 536-540. [CrossRef]

6. PDF4PRO. Available online: https://pdf4pro.com/view/the-state-of-world-fisheries-and-aquaculture-187a.html (accessed on 11 March 2021).

7. European Commission. Available online: https://ec.europa.eu/fisheries/press/eu-fish-market-2019-edition-out-everythingyou-wanted-know-about-eu-market-fish-and-seafood_en (accessed on 11 March 2021).

8. EUMOFA. Available online: https:/ / www.eumofa.eu/market-analysis\#yearly (accessed on 11 March 2021).

9. European Commission. Available online: https:/ / ec.europa.eu/ fisheries/eumofa-monthly-highlights-12018_en (accessed on 11 March 2021).

10. Olsgard, F.; Schaanning, M.T.; Widdicombe, S.; Kendall, M.A.; Austen, M.C. Effects of Bottom Trawling on Ecosystem Functioning. J. Exp. Mar. Biol. Ecol. 2008, 366, 123-133. [CrossRef]

11. Pardo, M.Á.; Jiménez, E.; Viðarsson, J.R.; Ólafsson, K.; Ólafsdóttir, G.; Daníelsdóttir, A.K.; Pérez-Villareal, B. DNA Barcoding Revealing Mislabelling of Seafood in European Mass Caterings. Food Control 2018, 92, 7-16. [CrossRef]

12. Pardo, M.Á.; Jiménez, E.; Pérez-Villarreal, B. Misdescription Incidents in Seafood Sector. Food Control 2016, 62, 277-283. [CrossRef]

13. Kroetz, K.; Luque, G.M.; Gephart, J.A.; Jardine, S.L.; Lee, P.; Moore, K.C.; Cole, C.; Steinkruger, A.; Josh Donlan, C. Consequences of Seafood Mislabelling for Marine Populations and Fisheries Management. Proc. Natl. Acad. Sci. USA 2020, 117, 30318-30323. [CrossRef]

14. Triantafyllidis, A.; Karaiskou, N.; Perez, J.; Martinez, J.L.; Roca, A.; Lopez, B.; Garcia-Vazquez, E. Fish Allergy Risk Derived from Ambiguous Vernacular Fish Names: Forensic DNA-Based Detection in Greek Markets. Food Res. Int. 2010, 43, $2214-2216$. [CrossRef]

15. Barcaccia, G.; Lucchin, M.; Cassandro, M. DNA Barcoding as a Molecular Tool to Track down Mislabelling and Food Piracy. Diversity 2016, 8, 2. [CrossRef]

16. Kochzius, M.; Seidel, C.; Antoniou, A.; Botla, S.K.; Campo, D.; Cariani, A.; Vazquez, E.G.; Hauschild, J.; Hervet, C.; Hjörleifsdottir, S.; et al. Identifying Fishes through DNA Barcodes and Microarrays. PLoS ONE 2010, 5, e12620. [CrossRef]

17. Huxley-Jones, E.; Shaw, J.L.A.; Fletcher, C.; Parnell, J.; Watts, P.C. Use of DNA Barcoding to Reveal Species Composition of Convenience Seafood. Conserv. Biol. 2012, 26, 367-371. [CrossRef]

18. Hebert, P.D.N.; Cywinska, A.; Ball, S.L.; de Waard, J.R. Biological identifications through DNA barcodes. Proc. Natl. Acad. Sci. USA 2003, 270, 313-321. [CrossRef] [PubMed]

19. Ward, R.; Hanner, R.; Hebert, P. The campaign to DNA barcode all fishes, FISH-BOL. J. Fish Biol. 2009, 74, 329-356. [CrossRef]

20. Hebert, P.D.N.; Ratnasingham, S.; DeWaard, J.R. Barcoding Animal Life: Cytochrome c Oxidase Subunit 1 Divergences among Closely Related Species. Proc. R. Soc. B Biol. Sci. 2003, 270 (Suppl. 1), 96-99. [CrossRef] [PubMed]

21. Naaum, A.M.; Warner, K.; Mariani, S.; Hanner, R.H.; Carolin, C.D. Seafood Mislabelling Incidence and Impacts; Elsevier Inc.: Amsterdam, The Netherlands, 2016. [CrossRef]

22. Standal, D.; Bouwer Utne, I. Can Cod Farming Affect Cod Fishing? A System Evaluation of Sustainability. Mar. Policy 2007, 31, 527-534. [CrossRef]

23. Halldórsson, J.E.; Björnsson, B.; Gunnlaugsson, S.B. Feasibility of Ranching Coastal Cod (Gadus morhua) Compared with on-Growing, Full-Cycle Farming and Fishing. Mar. Policy 2012, 36, 11-17. [CrossRef]

24. Deconinck, D.; Volckaert, F.A.M.; Hostens, K.; Panicz, R.; Eljasik, P.; Faria, M.; Monteiro, C.S.; Robbens, J.; Derycke, S. A High-Quality Genetic Reference Database for European Commercial Fishes Reveals Substitution Fraud of Processed Atlantic Cod (Gadus morhua) and Common Sole (Solea solea) at Different Steps in the Belgian Supply Chain. Food Chem. Toxicol. 2020, 141, 111417. [CrossRef]

25. Bréchon, A.L.; Hanner, R.; Mariani, S. A Systematic Analysis across North Atlantic Countries Unveils Subtleties in Cod Product Labelling. Mar. Policy 2016, 69, 124-133. [CrossRef]

26. Kappel, K.; Schröder, U. Substitution of High-Priced Fish with Low-Priced Species: Adulteration of Common Sole in German Restaurants. Food Control 2016, 59, 478-486. [CrossRef]

27. Günther, B.; Raupach, M.J.; Knebelsberger, T. Full-length and mini-length DNA barcoding for the identification of seafood commercially traded in Germany. Food Control 2017, 73, 922-929. [CrossRef]

28. Miller, D.; Jessel, A.; Mariani, S. Seafood Mislabelling: Comparisons of Two Western European Case Studies Assist in Defining Influencing Factors, Mechanisms and Motives. Fish Fish. 2012, 13, 345-358. [CrossRef]

29. Di Pinto, A.; Di Pinto, P.; Terio, V.; Bozzo, G.; Bonerba, E.; Ceci, E.; Tantillo, G. DNA Barcoding for Detecting Market Substitution in Salted Cod Fillets and Battered Cod Chunks. Food Chem. 2013, 141, 1757-1762. [CrossRef]

30. Bénard-Capelle, J.; Guillonneau, V.; Nouvian, C.; Fournier, N.; Le Loët, K.; Dettai, A. Fish mislabelling in France: Substitution rates and retail types. PeerJ 2015, 2, e714. [CrossRef] [PubMed]

31. Helgoe, J.; Oswald, K.J.; Quattro, J.M. A Comprehensive Analysis of the Mislabelling of Atlantic Cod (Gadus morhua) Products in Spain. Fish. Res. 2020, 222, 105400. [CrossRef]

32. Miller, D.D.; Mariani, S. Smoke, Mirrors, and Mislabelled Cod: Poor Transparency in the European Seafood Industry. Front. Ecol. Environ. 2010, 8, 517-521. [CrossRef] 
33. Estoup, A.; Largiader, C.R.; Perrot, E.; Chourrout, D. Rapid one-tube DNA extraction for reliable PCR dectection of fish polymorphic markers and transgenes. Mol. Mar. Biol. Biotechnol. 1996, 5, 295-298.

34. Handy, S.M.; Deeds, J.R.; Ivanova, N.V.; Hebert, P.D.; Hanner, R.H.; Ormos, A.; Yancy, H.F. A single-laboratory validated method for the generation of DNA barcodes for the identification of fish for regulatory compliance. J. AOAC Int. 2011, 94, 201-210. [CrossRef] [PubMed]

35. Ward, R.D.; Zemlak, T.S.; Innes, B.H.; Last, P.R.; Hebert, P.D. DNA barcoding Australia's fish species. Philos. Trans. R. Soc. B Biol. Sci. 2005, 360, 1847-1857. [CrossRef]

36. Hall, T.A. BioEdit: A user-friendly biological sequence alignment editor and analysis program for Windows 95/98/NT. In Nucleic Acids Symposium Series; Information Retrieval Ltd.: London, UK, 1999; Volume 41, pp. 95-98, c1979-c2000.

37. Filonzi, L.; Chiesa, S.; Vaghi, M.; Nonnis Marzano, F. Molecular Barcoding Reveals Mislabelling of Commercial Fish Products in Italy. Food Res. Int. 2010, 43, 1383-1388. [CrossRef]

38. Cutarelli, A.; Amoroso, M.G.; De Roma, A.; Girardi, S.; Galiero, G.; Guarino, A.; Corrado, F. Italian Market Fish Species Identification and Commercial Frauds Revealing by DNA Sequencing. Food Control 2014, 37, 46-50. [CrossRef]

39. Harris, D.J.; Rosado, D.; Xavier, R. DNA Barcoding Reveals Extensive Mislabelling in Seafood Sold in Portuguese Supermarkets. J. Aquat. Food Prod. Technol. 2016, 25, 1375-1380. [CrossRef]

40. Helyar, S.J.; Lloyd, H.D.; De Bruyn, M.; Leake, J.; Bennett, N.; Carvalho, G.R. Fish Product Mislabelling: Failings of Traceability in the Production Chain and Implications for Illegal, Unreported and Unregulated (IUU) Fishing. PLoS ONE 2014, 9, e98691. [CrossRef]

41. Muñoz-Colmenero, M.; Blanco, O.; Arias, V.; Martinez, J.L.; Garcia-Vazquez, E. L'authentification ADN Des Produits Halieutiques Révèle Un Mauvais Étiquetage Associé Au Traitement Des Fruits de Mer. Fisheries 2016, 41, 128-138. [CrossRef]

42. Christiansen, H.; Fournier, N.; Hellemans, B.; Volckaert, F.A.M. Seafood Substitution and Mislabelling in Brussels' Restaurants and Canteens. Food Control 2018, 85, 66-75. [CrossRef]

43. Pardo, M.Á.; Jiménez, E. DNA Barcoding Revealing Seafood Mislabelling in Food Services from Spain. J. Food Compos. Anal. 2020, 91, 103521. [CrossRef]

44. Minoudi, S.; Karaiskou, N.; Avgeris, M.; Gkagkavouzis, K.; Tarantili, P.; Triantafyllidou, D.; Palilis, L.; Avramopoulou, V.; Tsikliras, A.; Barmperis, K.; et al. Seafood Mislabelling in Greek Market Using DNA Barcoding. Food Control 2020, 113, 107213. [CrossRef]

45. Barendse, J.; Roel, A.; Longo, C.; Andriessen, L.; Webster, L.M.I.; Ogden, R.; Neat, F. DNA Barcoding Validates Species Labelling of Certified Seafood. Curr. Biol. 2019, 29, R198-R199. [CrossRef] [PubMed]

46. Mariani, S.; Ellis, J.; O’Reilly, A.; Bréchon, A.L.; Sacchi, C.; Miller, D.D. Mass Media Influence and the Regulation of Illegal Practices in the Seafood Market. Conserv. Lett. 2014, 7, 478-483. [CrossRef]

47. Horreo, J.L.; Fitze, P.S.; Jiménez-Valverde, A.; Noriega, J.A.; Pelaez, M.L. Amplification of 16S RDNA Reveals Important Fish Mislabelling in Madrid Restaurants. Food Control 2019, 96, 146-150. [CrossRef]

48. Gilman, E.; Legorburu, G.; Fedoruk, A.; Heberer, C.; Zimring, M.; Barkai, A. Increasing the Functionalities and Accuracy of Fisheries Electronic Monitoring Systems. Aquat. Conserv. Mar. Freshw. Ecosyst. 2019, 29, 901-926. [CrossRef]

49. Vlachopoulou, E.I.; Wilson, A.M.; Miliou, A. Disconnects in EU and Greek Fishery Policies and Practices in the Eastern Aegean Sea and Impacts on Posidonia Oceanica Meadows. Ocean Coast. Manag. 2013, 76, 105-113. [CrossRef]

50. Food and Agriculture Organization of the United Nations. Available online: http://www.fao.org/fishery/area/Area27/en (accessed on 11 March 2021).

51. Food and Agriculture Organization of the United Nations. Available online: http://www.fao.org/tempref/FI/maps/fig_h4_67_ 0.gif (accessed on 11 March 2021).

52. Pedersen, E.J.; Thompson, P.L.; Ball, R.A.; Fortin, M.J.; Gouhier, T.C.; Link, H.; Moritz, C.; Nenzen, H.; Stanley, R.R.E.; Taranu, Z.E.; et al. Signatures of the Collapse and Incipient Recovery of an Overexploited Marine Ecosystem. R. Soc. Open Sci. 2017, 4, 170215. [CrossRef] [PubMed]

53. Årthun, M.; Bogstad, B.; Daewel, U.; Keenlyside, N.S.; Sandø, A.B.; Schrum, C.; Ottersen, G. Climate Based Multi-Year Predictions of the Barents Sea Cod Stock. PLoS ONE 2018, 13, e0206319. [CrossRef]

54. Guggisberg, S. The EU's Regulation on the Sustainable Management of External Fishing Fleets: International and European Law Perspectives. Int. J. Mar. Coast. Law 2019, 34, 291-324. [CrossRef] 